\title{
コミュニティ道路の整備要望度の分析* Analysis of the Attitude for Developing Traffic Calming Roads*
}

\author{
杉恵 頼寧 ${ }^{* *}$ ・藤原 章正 ${ }^{* *}$ ・田辺 博樹*** \\ By Yoriyasu SUGIE**, Akimasa FUJIWARA** and Hiroki TANABE***
}

\section{1.はじめに}

住区内道路では自動車交通の増大に伴い、ますます 通過交通の進入等による交通事故の多発や、歩行環境 の悪化などの深刻な問題が生じている。このような社 会状況を呈する中で、従来の交通の円滑化を目指した 道路整備事業に加え、地区交通の安全性の向上を目的 として、コミュニティ道路整備事業やコミュニティ・ ゾーン形成事業などを促進し、将来の高齢化社会に対 応できる交通環境の整備が望まれている。

この整備事業の立役者となるのが、歩車共存道路の 代表的存在であるコミュニティ道路である。コミュニ ティ道路は、オランダのボンエルフをその発祥として おり ${ }^{1)} 、$ 我が国では1980年に大阪市阿倍野区長池町で 第1号が誕生し、現在まで大阪市、名古屋市を中心に、 約600箇所余りが歩車共存道路として整備されている゙2。 このような現状の中、現在の事業の問題点と将来にお けるコミュニティ道路の在り方に対する考察が必要と なっている。

そこで、コミュニティ道路設置後の交通事故の減少 や通過交通量の減少、速度の低下等の物理的効果に関 する研究 ${ }^{3) 4}$ や、すでに整備されたコミュニティ道路に 対する住民の事後評価に関する研究 ${ }^{5) 6}$ が今日まで多く なされてきた。我々も広島市のコミュニティ道路に対 する意識調查を実施し、コミュニティ道路のデバイス の整備と、それに対する周辺住民の心理的評価及び沿 道交通に及ぼす影響を示す物理的効果との因果関係を 分析した7)。

コミュニティ道路はそのほとんどが単一路線での整 備であり、地域によっては十分な効果が期待できない ところもある。そこで、この線としての交通安全対策 を面に広げていくことの必要性が高まっている。面的 整備にすると、その整備効果は単一路線の整備に比べ て格段に大きくなるが8)、関係住民が多くなり、彼ら の合意を得ることが困難になる。1996年に創設された コミュニティ・ゾーン形成事業は住民参加プロセスを

*キーワード : 地区交通計画、意識調査分析

**正会員 工博 広島大学大学院国際協力研究科

（テ739-8529 東広島市鏡山 1-5-1, Tel\&Fax: 0824-24-6919）

***正会員 工修 荒谷建設コンサルタント

（广730-0831 広島市中区江波西 1-25-5, Tel: 082-292-5481）
重要視しており9)、事業への住民参加や合意形成手法 についての研究 ${ }^{10,11)}$ もられるようになっている。

本研究は、このような背景の基に、先の研究”のデー 夕にその後整備された地区の調査デー夕を加え、現在 のコミュニティ道路整備事業に対する住民の評価と問 題点を整理するとともに、共分散構造モデルを用いて コミュニティ道路に対する整備要望度の意識構造分析 を行い、コミュニティ道路の拡充 (面的整備) のため の知見を得ようとするものである。

\section{2. コミュニティ道路に対する意識調査と集計結果}

（1）調査対象地区と整備内容

平成10年現在、広島市は皆実・舟入・草津・白島 ・ 緑井・丹那・観音・横川の8地区にコミュニティ道路を 整備している。本研究では 8 つ地区から、表-1に示す ように歩道拡幅が両側に施されている6路線（皆実・舟 入・草津・白島・観音・横川地区）を対象にコミュニ ティ道路に対する住民意識調査を実施した。皆実・舟 入・草津・白島・観音の各地区はいずれも都心部に隣 接した住居地域に位置し、一方通行の交通規制がかかっ ている。整備の内容は、表-2に示すように、ジグザグ の車道（クランク）を中心に歩道のカラー舗装、植栽 による道路の美装化が基本になっている。横川地区は 駅前の商業地域に位置し、交通安全よりも沿道の商店 街の活性化を重視した整備となっている。

\section{（2）住民意識調査}

調查票は被験者にコミュニティ道路が何であるかを 知ってもらうために対象道路の位置・定義などを簡単 に示した表紙から始まり、1）対象道路の通行状況の質 問項目を含んだ個人属性、2) コミュニティ道路の事後 評価に関する質問、3）住区内道路全体についての評価 に関する質問と大きく3つに分れている。項目2）、3） の質問では、歩行者を通行する車から守る安全性、歩 行者の通行がしやすい快適性、地区の環境を向上させ る美観性という交通静穏化の3つの主要な構成概念に着 目して質問内容を決定し、各々の観測変数は5段階ある いは3段階の評価づけとした。

調査にあたっては、コミュニティ道路の整備されて いる地区の居住者を対象に無差別に抽出した。表-3に 示すように観音・横川を除く4路線は平成7年9月、観音・ 
表-1 コミュニティ道路の概要

\begin{tabular}{|c|c|c|c|c|c|}
\hline & 場 & 所 & 整備年度 & 延長(m) & 幅員(m) \\
\hline 1. & 南区 & 皆実 & S58 & 255.6 & 8.0 \\
\hline 2. & 中区 & 舟入 & S59 & 144.5 & 10.0 \\
\hline 3. & 西区 & 草津 & S61 & 273.1 & 11.0 \\
\hline 4. & 中区 & 白島 & $\mathrm{H} 1$ & 150.0 & 8.0 \\
\hline 5. & 西区 & 観音 & H8 & 274.0 & 8.0 \\
\hline 6. & 西区 & 横川 & $\mathrm{H} 8$ & 370.0 & 8.0 \\
\hline
\end{tabular}

表-2 コミュニティ道路の整備内容

\begin{tabular}{l|cccccc}
\hline \multicolumn{1}{c|}{ デバイス } & 皆実 & 舟入 & 草津 & 白島 & 観音 & 横川 \\
\hline クランク/フォルト & $\bigcirc$ & $\bigcirc$ & $\bigcirc$ & $\bigcirc$ & $\bigcirc$ & \\
スラローム & & & & & & $\bigcirc$ \\
イメージハンプ & $\bigcirc$ & $\bigcirc$ & $\bigcirc$ & & $\bigcirc$ & $\bigcirc$ \\
照明装置 & $\bigcirc$ & $\bigcirc$ & $\bigcirc$ & $\bigcirc$ & $\bigcirc$ & $\bigcirc$ \\
植栽 & $\bigcirc$ & $\bigcirc$ & $\bigcirc$ & $\bigcirc$ & $\bigcirc$ & $\bigcirc$ \\
カラー舖装 & $\bigcirc$ & $\bigcirc$ & $\bigcirc$ & $\bigcirc$ & $\bigcirc$ & $\bigcirc$ \\
ボラード & $\bigcirc$ & $\bigcirc$ & $\bigcirc$ & $\bigcirc$ & $\bigcirc$ & $\bigcirc$ \\
駐車スペース & $\bigcirc$ & $\bigcirc$ & & & & \\
\hline
\end{tabular}

表-3 調查結果

\begin{tabular}{lcccccc}
\hline 地区 & 配布数 & 回収数 & 回収率 & $\begin{array}{l}\text { 有効 } \\
\text { 回答数 }\end{array}$ & $\begin{array}{l}\text { 有効 } \\
\text { 回収率 }\end{array}$ & 調査年月 \\
\hline 皆実 & 237 & 216 & $91.1 \%$ & 199 & $84.0 \%$ & H7年9月 \\
舟入 & 214 & 187 & 87.4 & 174 & 81.3 & \\
草津 & 250 & 228 & 91.2 & 226 & 90.4 & \\
白島 & 218 & 198 & 90.8 & 181 & 83.0 & \\
観音 & 256 & 233 & 91.0 & 220 & 85.9 & H8年9月 \\
\hline 横川 & 426 & 340 & 81.7 & 320 & 75.1 & H9年 $11 月$ \\
\hline 合計 & 1,601 & 1,402 & 87.5 & 1,320 & 82.4 & \\
\hline
\end{tabular}

横川路線はその整備直後それぞれ平成8年9月、平成9年 11月に別々に調査した。これら3調查を合わせた総配布 数1,601枚に対して回収率は約 $87.5 \%$ あ゙あ、白㻃を除 いた有効回答率は総配布枚数に対して $82.4 \%$ と非常に 良好な結果であった。

\section{3. コミュニティ道路に対する住民の評価}

\section{（1）コミュニテイ道路の認知度}

図-1は、調查対象路線がコミュニティ道路と呼ばれ ることを知っていたかどうかを、アンケートを実施し た時点で、「知っていた」、「名前は知らなかったが 普通の道路と違うことを知っていた」、「知らなかっ た」の3段階で質問したものである。皆実・白島では住 民の約 $50 \%$ 以上が知らなかったと答えた。反対に、そ の他の地区では、普通の道路と違うことを知っていた と回答した人を含めると、約 $60 \%$ 以上の住民がコミュ ニティ道路を認知していることになる。特に、普通の 道路と違うと感じていた人の割合は観音・横川地区で 大きくなっている。
最初に調査した 4 地区での認知度の差は、舟入・草 津路線と皆実・白島路線の整備内容の違いによると考 えられる。特に植栽は、皆実 (12本) 、白島 (16本) であるのに対して、舟入 (31本) 、草津（65本）であ り、被験者が、明らかに視覚的に道路の違いを認識し やすくなっている。また、新設された観音路線では、

「知っていた」と、「違いのみ知っていた」と回答し た人の合計が、約 $65 \%$ に達している。住民が、住宅地 区に新しく設置されたコミュニティ道路に高い関心を 寄せていることがわかる。

\section{（2）コミュニティ道路の賛成度}

図-2は、整備されたコミュニティ道路に対して総合 的に賛成かどうかを5段階で質問したものを3段階で示 した。全体的に反対（反対+どちらかといえば反対） よりも賛成（賛成+どちらかといえば賛成）がより多 くなっている。白島路線では、コミュニティ道路に賛 成と回答した人の割合が $34 \%$ と最も低い。反対と答え た住民も $29 \%$ であることを考えると、38\%の人がどち らとも言えないと回答していることになり、白島地区 の住民がコミュニティ道路に対してなじんでいないこ とが伺える。逆に、観音・横川地区のコミュニティ道 路に対する評価は非常に高く、特に横川は73\%の人が 賛成しており、住民の反響が高いことがわかる。

\section{（3）コミュニティ道路の整備要望度}

図-3はコミュニティ道路が整備されていない道路沿 いの世帯に対し、自宅前の道路にコミュニティ道路が 整備されることに賛成か反対か（以後、整備要望度） を質問した結果である。各路線ともコミュニティ道路 の整備要望度はそれほど高いものとはいえず、特に白 島の整備要望度は低い。また観音・横川は図-2の賛成 度が非常に高かったにもかかわらず、整備要望度は他 の地区と同程度まで低くなっている。全体的に見て、 「どちらでもない」という中立的な立場の人が多く、 コミュニティ道路の賛成度は比較的高いにもかかわら ず、整備要望度になるとそれほど高い支持を得られな かった。この結果は我々の予想に反するものであり、 この原因を探ることは、今後のコミュニティ道路の整 備を拡充していくうえで重要なことである。

（4）住区内道路の満足度とコミュニティ道路の整備要 望度との関係

図-4をみると、住区内道路に満足している人はコミュ ニティ道路の整備要望度が低い。逆に、住区内道路に 不満な人はコミュニティ道路の整備要望度が高い。現 在の住区内道路の評価がコミュニティ道路の整備要望 度を決定する主要な要因の一つであることがわかる。 


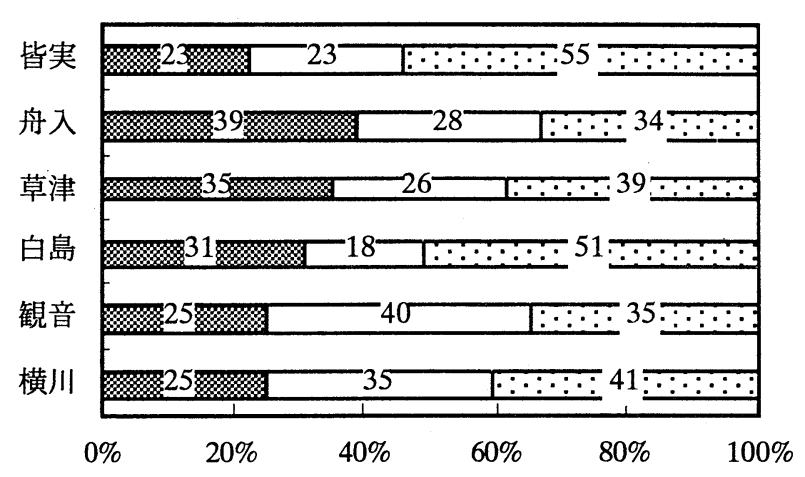

四知っていたロ違いのみ四知らなかった

図-1 コミュニティ道路の認知度

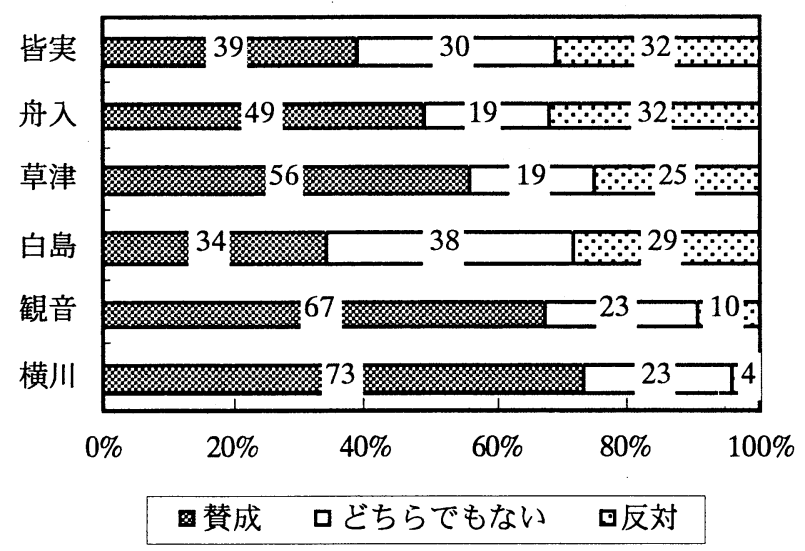

図-2 コミュニティ道路の賛成度

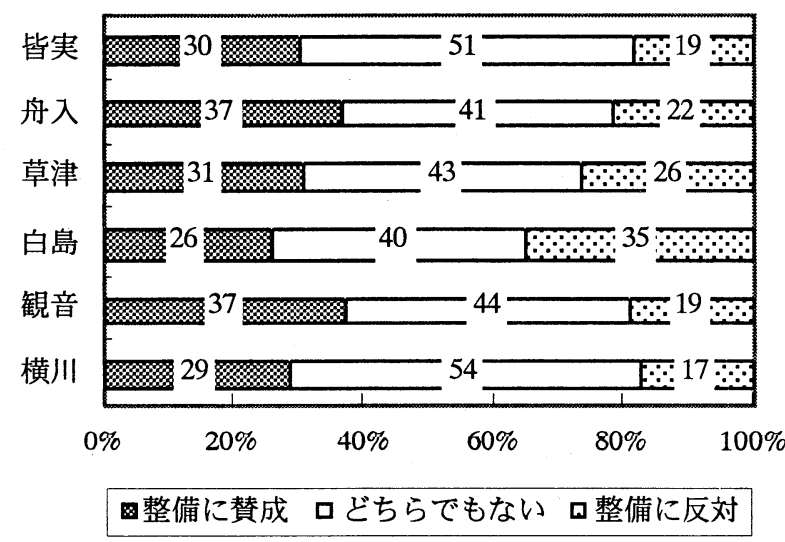

図-3 コミュニティ道路の整備要望度

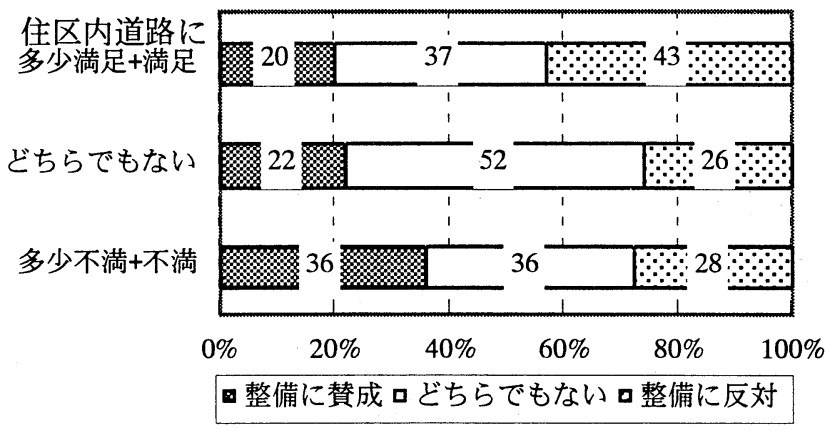

図-4 住区内道路の満足度と整備要望度の関係

\section{4. コミュニティ道路整備要望度の要因分析}

地区によってコミュニティ道路の整備要望度が大き く異なる要因を数量化 II 類を用いて分析した（表-4）。 外的基準は、コミュニティ道路の新たな整備に対して、 賛成、どちらでもない、反対の3段階である。まず、コ ミュニティ道路の賛成度、住区内道路の満足度、居住 年数、職業の順で偏相関係数が高く、コミュニティ道 路整備要望度に対して重要な要因であることが分かる。

住区に関しては、やはり地区によってばらつきがあ るが、偏相関係数が小さく、その評価の差は相対的に 小さくなっている。居住年数では、年数の短い人ほど 整備要望度が高い。交通弱者は、世帯内にいる方がい ない場合よりも整備要望度が高い。職業別では、自営 業者の整備要望度が低いのが目立つ。住区内道路の満 足度についてみると、現状の住区内道路に不満を感じ ている人ほど整備要望度が高い。自宅からコミュニティ 道路までの距離は、あまり影響力がないようである。

\section{表-4 整備要望度の要因分析}

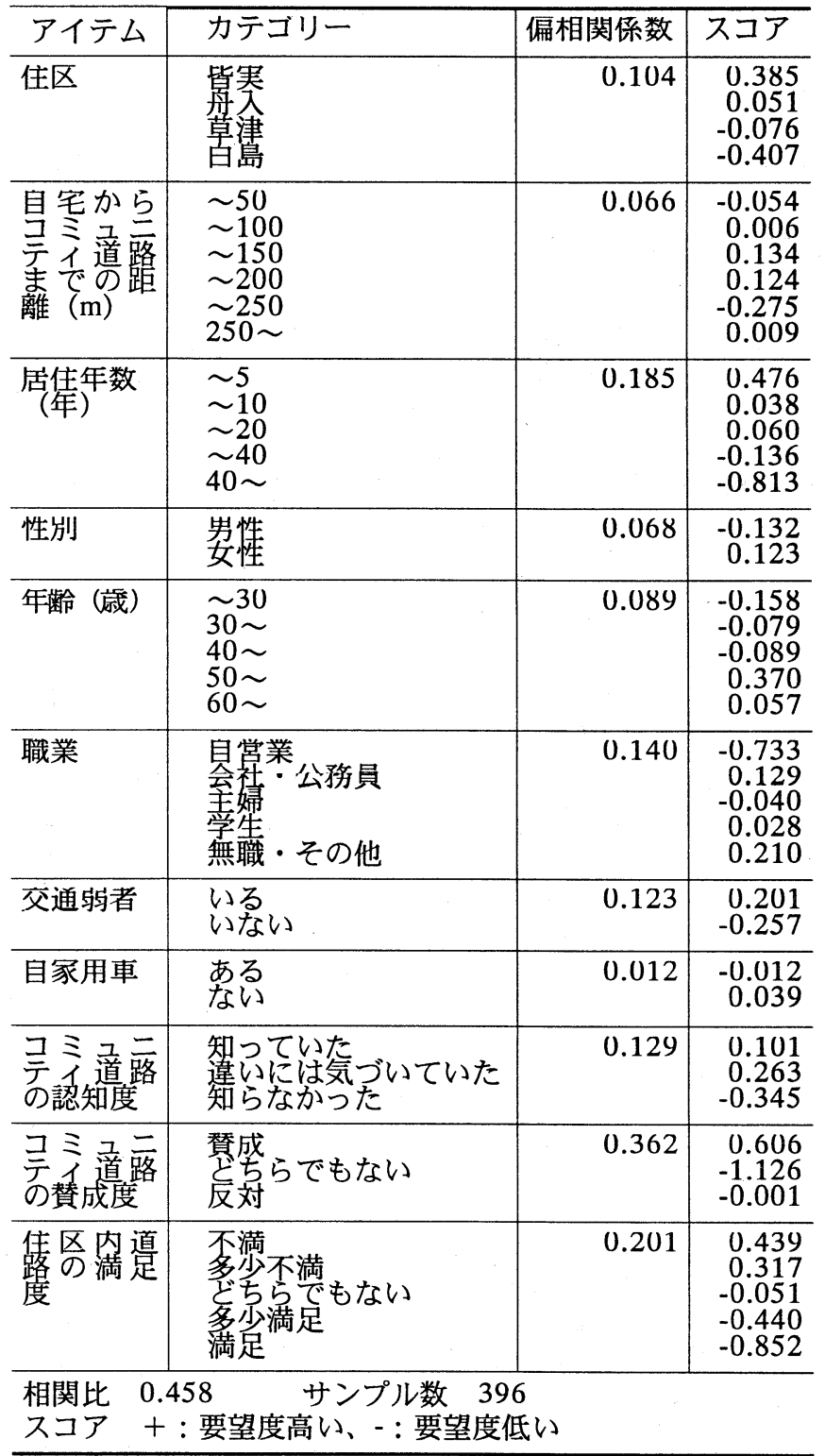


コミュニティ道路の賛成度では、「どちらでもない」 が「反対」よりもコミュニティ道路の整備要望度が低 くなっている。この原因を分析するため、まずコミュ ニティ道路の道路整備要望度と賛成度の関係を全調査 データで示すと、図-5のようになる。これは表-4の分 析結果をより明確に示すものである。

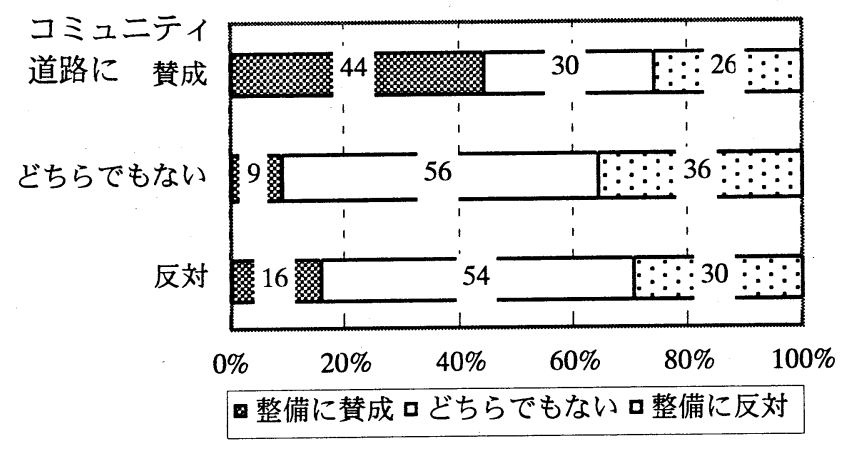

図-5 コミュニティ道路の賛成度と整備要望度の関係

表-5 グループ別整備要望度の要因分析

\begin{tabular}{|c|c|c|c|}
\hline アイテム & カテゴリー & $\begin{array}{c}\text { 賛成グル-プ } \\
\text { のスコア }\end{array}$ & $\begin{array}{c}\text { 中立グルレブ } \\
\text { のスコア }\end{array}$ \\
\hline 住区 & $\begin{array}{l}\text { 皆実 } \\
\text { 䒜入 } \\
\text { 菖津 } \\
\text { 帛 }\end{array}$ & $\begin{array}{r}(0.144) \\
-0.448 \\
0.283 \\
-0.036 \\
0.135 \\
\end{array}$ & $\begin{array}{r}(0.369) \\
0.653 \\
0.598 \\
-0.402 \\
-0.764\end{array}$ \\
\hline $\begin{array}{l}\text { 慁宅からコ } \\
\text { 道路までの } \\
\text { 距離 }(\mathrm{m})\end{array}$ & $\begin{array}{l}\sim 50 \\
\sim 100 \\
\sim 150 \\
\sim 200 \\
\sim 250 \\
\sim 250 \sim\end{array}$ & $\begin{array}{r}(0.197) \\
0.006 \\
0.016 \\
0.429 \\
-0.076 \\
0.979 \\
0.126\end{array}$ & $\begin{array}{r}(0.251) \\
-0.163 \\
0.523 \\
-0.448 \\
0.593 \\
-0.604 \\
0.187\end{array}$ \\
\hline $\begin{array}{l}\text { 居佳年数 } \\
\text { (年) }\end{array}$ & $\begin{array}{l}\sim 5 \\
\sim 10 \\
\sim 20 \\
\sim 40 \\
\sim 40 \sim\end{array}$ & $\begin{array}{r}(0.225) \\
0.524 \\
-0.283 \\
0.431 \\
-0.149 \\
-0.889\end{array}$ & $\begin{array}{r}(0.330) \\
0.757 \\
0.130 \\
-0.417 \\
0.101 \\
-0.998\end{array}$ \\
\hline 性別 & 男性 & $\begin{array}{r}(0.124) \\
-0.199 \\
0.252\end{array}$ & $\begin{array}{r}(0.023) \\
-0.055 \\
0.033\end{array}$ \\
\hline 年齢（歳） & $\begin{array}{l}\sim 30 \\
30 \sim \\
40 \sim \\
50 \sim \\
60 \sim\end{array}$ & \begin{tabular}{r|}
$(0.086)$ \\
-0.104 \\
-0.145 \\
-0.171 \\
0.195 \\
0.206
\end{tabular} & $\begin{array}{r}(0.250) \\
0.184 \\
0.296 \\
-0.539 \\
0.567 \\
-0.299\end{array}$ \\
\hline 職業 & $\begin{array}{l}\text { 筫営業 } \\
\text { 卦公務員 } \\
\text { 労生 } \\
\text { 無職・その他 }\end{array}$ & $\begin{array}{r}(0.222) \\
-1.095 \\
0.243 \\
0.077 \\
0.023 \\
0.078\end{array}$ & $\begin{array}{r}(0.311) \\
-0.546 \\
0.380 \\
-0.545 \\
-0.277 \\
1.228\end{array}$ \\
\hline $\begin{array}{l}\text { 住区内道路 } \\
\text { の満足度 }\end{array}$ & $\begin{array}{l}\text { 不満 } \\
\text { 多少不満 } \\
\text { 芯゙ない } \\
\text { 多少満足 } \\
\text { 満足 }\end{array}$ & \begin{tabular}{r|}
$(0.328)$ \\
0.635 \\
0.633 \\
-0.187 \\
-0.747 \\
-1.001
\end{tabular} & $\begin{array}{r}(0.226) \\
1.120 \\
0.162 \\
-0.189 \\
-0.585 \\
-0.121\end{array}$ \\
\hline \multicolumn{2}{|c|}{ 相関比/サンプル数 } & $0.482 / 186$ & $0.557 / 100$ \\
\hline
\end{tabular}

つづいて、「コミュニティ道路の賛成度」について 「賛成」と答えた人のデータのみを取り出し、表-4 と 同様にコミュニティ道路整備要望度の要因分析を行っ た（表-5の賛成グループ）。その結果、住区内道路の 満足度との偏相関係数が高くなった。スコアの值から、 コミュニティ道路に賛成でも住区内道路に満足してい れば、コミュニテイ道路を整備要望しない傾向にある ことがわかった。また自営業者や居住年数が 40 年以上 の人は、コミュニティ道路に賛成であっても、自宅前 にはコミュニティ道路を要望しないことがわかった。

つぎに、「コミュニティ道路の賛成度」について 「どちらでもない」と答えた人のデータのみを取り出 し、同様な分析を行った（表-5の中立グループ）。相 関比が高くなっているのは、外的基準の「賛成」が9\% しかなく、実質的に 2 項選択に近くなっているためと考 えられる。偏相関係数は、住区が一番大きく、住区内 道路の満足度が相対的に低くなり、コミュニティ道路 の賛成度について「どちらでもない」人は、住区内道 路の満足度以外の地区特性も整備要望度に大きく影響 しているものと考えられる。

\section{5. コミュニティ道路の意識構造分析}

コミュニティ道路の整備要望度は、住区内道路の評 価や個人の特性等様々な要因により決定されると考え られるため、その因果関係を共分散構造モデル ${ }^{12)}$ を構 築して分析を行う。

共分散構造モデルは、測定方程式と構造方程式とい う2種類の方程式によって表される。測定方程式は式 (2)、(3)のように潜在変数（測定される多くの現象の背 後にあって、それらの現象に影響を与える要因で、目 に見えない仮説的な変数）が観測変数（実際に值が測 定される変数）に影響を与えている様子を記述する方 程式であり、構造方程式は式(1)のように潜在変数の因 果関係を記述する方程式である。

$$
\begin{aligned}
& \eta=\mathrm{B} \eta+\Gamma \xi+\zeta \\
& \mathrm{Y}=\kappa \eta+\varepsilon \\
& \mathrm{X}=\lambda \xi+\delta
\end{aligned}
$$

ただし、 $\eta$ : 内生潜在変数、 $\xi$ : 外生潜在変数、 $\mathrm{Y}$ : 内生観測変数、 $\mathrm{X}$ : 外生観測変数、 $\mathrm{B}, \Gamma, \kappa, \lambda:$ 未知 パラメータ、 $\zeta, \varepsilon, \delta:$ 誤差項

これまでの分析結果から、コミュニティ道路の整備 要望度は「コミュニティ道路の評価」、「住区内道路 の評価」、「住区内道路への要望」、「自宅周辺の道 路環境」、「個人の特性」によって大きく決定される と仮定した。これらを潜在変数とし、その因果関係を 示したのが図-5である。ここで、「地区内道路の評価」 は「コミュニティ道路の評価」や「住区内道路への要 望」に、「住区内道路への要望」は「コミュニティ道 


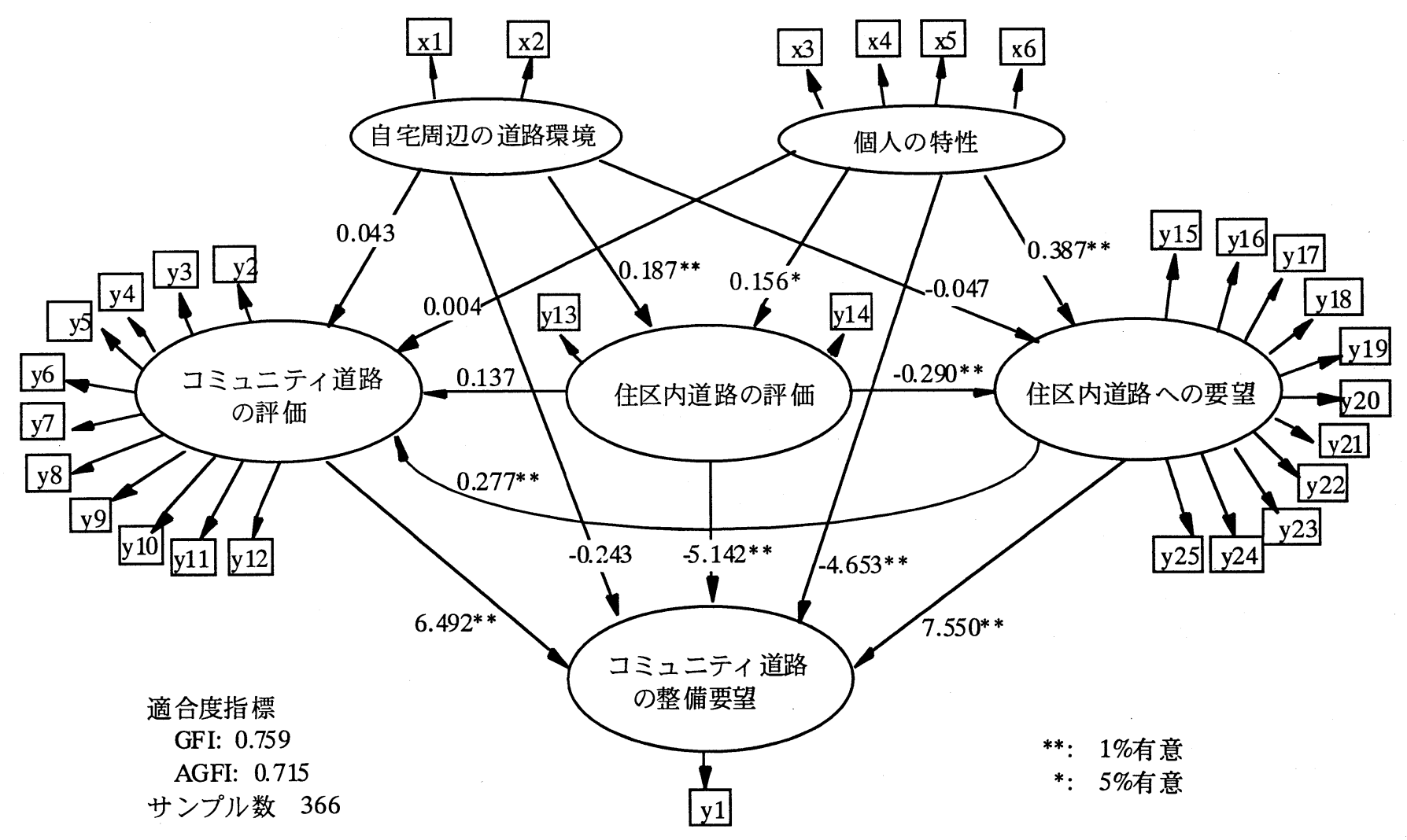

図-6 コミュニティ道路の整備要望度の意識構造と構造方程式のパラメー夕推定値

表-6 観測変数と測定方程式のパラメータの推定值

\begin{tabular}{|c|c|c|}
\hline 変数 & 変数の説明 & パタメ-タ(t值) \\
\hline $\begin{array}{l}\mathrm{x} 1 \\
\mathrm{x} 2\end{array}$ & $\begin{array}{l}\text { 歩道の有無 (有 }=1 \text { 、無 }=0) \\
\text { 自宅前の道路幅員 }(\mathrm{m})\end{array}$ & $\begin{array}{l}1.431(2.0)^{*} \\
0.496(-)\end{array}$ \\
\hline $\begin{array}{l}\mathrm{x} 3 \\
\mathrm{x} 4 \\
\mathrm{x} 5 \\
\mathrm{x} 6\end{array}$ & $\begin{array}{l}\text { 年齢 } \\
\text { 性別（男性=1、女性=0） } \\
\text { 居住年数 } \\
\text { コミュニテ道路までの距離 }\end{array}$ & $\begin{array}{l}0.939(-) \\
-0.270(4.6)^{* *} \\
0.665(7.9)^{* *} \\
0.313(2.8)^{* *}\end{array}$ \\
\hline $\mathrm{y} 1$ & コミュニティ道路の整備要望度 & $0.046(-)$ \\
\hline $\begin{array}{l}\text { y2 } \\
\text { y3 } \\
\text { y4 } \\
\text { y5 } \\
\text { y6 } \\
\text { y7 } \\
\text { y8 } \\
\text { y9 } \\
\text { y10 } \\
\text { y11 } \\
\text { y12 }\end{array}$ & $\begin{array}{l}\text { コミュニティ道路の認知度 } \\
\text { すれ違いのしやすさ } \\
\text { クランクによる速度の低下 } \\
\text { カラーブロックによる速度の低下 } \\
\text { 歩道の拡張 } \\
\text { 交通量の減少 } \\
\text { 騒音・振動の増加 } \\
\text { 違法駐車の増加 } \\
\text { 照明施設の設備 } \\
\text { カラ一舗装 } \\
\text { 植栽の整備 }\end{array}$ & $\begin{array}{l}-0.313(5.7)^{*} \\
0.784(-) \\
0.629(12.0)^{* *} \\
0.699(13.6)^{* *} \\
0.732(14.3)^{* *} \\
0.746(14.6)^{* *} \\
-0.175(3.2)^{* *} \\
-0.232(4.2)^{* *} \\
0.568(10.8)^{* *} \\
0.594(11.3)^{* *} \\
0.689(13.4)^{* *}\end{array}$ \\
\hline $\begin{array}{l}\mathrm{y} 13 \\
\mathrm{y} 14 \\
\end{array}$ & $\begin{array}{l}\text { 住区内道路に対する満足度 } \\
\text { 住区内道路に対する危険度 }\end{array}$ & $\begin{array}{l}0.633(-) \\
-0.678(5.7) * *\end{array}$ \\
\hline $\begin{array}{l}\text { y15 } \\
\text { y16 } \\
\text { y17 } \\
\text { y18 } \\
\text { y19 } \\
\text { y20 } \\
\text { y21 } \\
\text { y22 } \\
\text { y } 23 \\
\text { y24 } \\
\text { y25 }\end{array}$ & $\begin{array}{l}\text { 通行車両の削減 } \\
\text { 通過交通の排除 } \\
\text { 騒音・振動の抑制 } \\
\text { 歩行者の優先 } \\
\text { 歩車共存 } \\
\text { 住民の交流スペース } \\
\text { 美観性の向上 } \\
\text { 照明施設の設置 } \\
\text { 駐車禁止 } \\
\text { 一方通行 } \\
\text { 速度規制 }\end{array}$ & $\begin{array}{l}0.761(-) \\
0.492(8.9)^{* *} \\
0.564(10.3)^{* *} \\
0.653(12.0)^{* *} \\
0.036(0.65) \\
0.466(8.5)^{* *} \\
0.665(12.3)^{* *} \\
0.399(7.2)^{* *} \\
0.406(7.3)^{* *} \\
0.592(10.9)^{* *} \\
0.711(13.2)^{* *}\end{array}$ \\
\hline
\end{tabular}

路の評価」にも影響し、「自宅周辺の道路環境」や 「個人の特性」は他の全ての潜在変数に影響するもの と仮定した。分析データは、これらの項目が同一時点 で共通して調查された皆実、舟入、草津、白島の4地区 のデータを以降使用する。

統計パッケージAMOSを用いた構造方程式の推定結 果を図-6に示す。観測変数の内容と測定方程式の推定 パラメータは表-6に示す。 $\mathrm{x} 1 、 \mathrm{x} 2 、 \mathrm{x} 6$ の3変数は実測值 であり、その他の変数は住民意識調査から得られたも のである。y3〜y12は、歩行者・自転車利用者としての 現存するコミュニティ道路の5段階評価であり、評価の 高い方から5〜1の点数を与えた。y15〜y 25 は住区内道 路に対する要望を5段階で示したものであり、その程度 の大きい方から5〜1の点数を与えた。y14は住区内道路 に対する危険度の3段階評価であり、y1、y2、y13は図1 〜3に示す通りである。評価や賛成度の高い方から3〜1 の点数を与えた。パラメータ（係数）は規準化されて いるので、その值が大きいパスが因果関係が大きいこ とを示す。モデルの適合度を示すGFIとAGFIは0.759 と 0.715 となっており、比較的良い值となっている。

まず、図-6の上段部にあたる「自宅周辺の道路環境」 と「個人の特性」からのパスをみてみる。パラメータ の符号から、歩道があって道路幅員が広いといった 「自宅周辺の道路環境」（x1,x2）がよい人ほど、「住 区内道路の評価」は高く $(0.187)$ 、「住区内道路への 要望」は低い $(-0.047)$ 。「個人の特性」は、年齢 
（x3）や居住年数（x5）のパラメー夕值が大きいこと から、地区との係りを示す潜在変数と考えられる。こ のことから地区との係りが大きいほど、「住区内道路 の評価」が高く (0.156) 、逆に「コミュニティ道路の 整備要望」は低い (-4.653) ことがわかる。

中段部と下段部の関係を見ると、パラメータの符号 から、「住区内道路の評価」が高いほど「住区内道路 への要望」が低い（-0.290）ことがわかる。そして 「住区内道路の評価」が高くなれば、「コミュニティ 道路の整備要望」も低くなる $(-5.142)$ 。「住区内道 路への要望」が高くなれば、直接的に「コミュニティ 道路の整備要望」は高くなる (7.550)。また間接効果 として「住区内道路への要望」が高くなれば、「コミュ ニティ道路の評価」が高くなり (0.277) 、「コミュニ ティ道路の評価」が高くなれば、「コミュニティ道路 の整備要望」は高くなる (6.492)。

全体的にみて、「コミュニティ道路の整備要望」は、 パラメータの大きさから、「住区内道路の評価」より も「住区内道路への要望」の影響力が大きいことがわ かる。

\section{6. 結論}

広島市でこれまで整備されたコミュニティ道路に対 する住民の事後評価を行った。整備されたコミュニティ 道路に対する住民の評価は高く、一般に新しい路線ほ ど賛成の割合が大きくなっている。しかし、自宅前の 新たなコミュニティ道路の整備に対しては、賛成の割 合がどの地区においても大幅に減少している。そこで、 コミュニティ道路の整備要望度に対する要因分析を数 量化II類を用いて行い、その意識構造を共分散構造モ デルを用いて分析した。

その結果、現存するコミュニティ道路に対して賛成/ 反対のどちらでもない人が、新たな整備を要望しない 傾向が明らかになった。しかし、これらの人々の整備 要望度に対する要因分析では、その要因を十分見い出
せなかった。今後その要因を明確にし、これらの人の 理解をどのようにして求めていくかが重要な課題にな るものと考えられる。

因果構造分析では、「住区内道路への要望」、「コ ミュニティ道路の評価」、「住区内道路の評価」と 「コミュニティ道路の整備要望」の因果構造を明確に することができた。

\section{参考文献}

1) オランダ王立ツーリングクラブ : オランダにおける WOONERF計画、人と車、昭和 53 年 1,2 月号、日本交 通安全協会、pp.33-47, 22-31、1978.

2）天野光三他: 歩車共存道路の計画 - 手法一快適な生 活空間を求めて一、都市文化社、1986.

3）土橋政彦他 : 歩車共存道路の整備効果と課題に関す る研究、土木計画学研究・講演集No.17、pp.311-314、 1995.

4）田村亨他：コミュニティ道路整備の事後評価、都市 計画論文集No.26、pp.229-234、1991

5) 久保田尚他: 歩車共存道路の使用後評価、土木学会 論文集No.449、pp.165-173、1992.

6）橋本成仁他 : コミュニティ道路に関する住民意識と 課題、第15回交通工学研究発表会論文報告集、 pp.169-172、1995.

7）杉恵頼寧他 : 広島市内におけるコミュニティ道路の 事後評価、第16回交通工学発表会論文報告集、 pp.133-136、 1996.

8）花田健司他：コミュニティーゾーンにおける安全対 策とその効果について、第18回交通工学発表会論文 報告集、pp.77-80、1998.

9）警察庁交通局／建設省都市局・道路局 : コミュニティー ・ゾーン形成マニュアル、交通工学研究会、1996.

10）山岡俊一他：地区交通整備事業の進捗段階と住民 参加の意識構造に関する研究、都市計画論文集 No.35、pp.433-438、 2000.

11）三谷麻衣他 : 参加型地区交通改善のための合意形 成手法に関する研究、都市計画論文集 No.35、 pp.487-492、2000.

12）豊田秀樹：原因をさぐる統計学、講談社、1992.

\section{コミュニティ道路の整備要望度の分析}

杉恵 頼寧・藤原 章正・田辺 博樹 本研究はコミュニティ道路の事後評価を行い、将来におけるコミュニティ道路の面的整備のあり方を探ろうとするものである。 そこで、広島市で既に整備されているコミュニティ道路を対象にアンケート調査を行い、共分散構造モデル、数量化II 類で分 析した結果、コミュニティ道路の整備要望度は、現在の住区内道路の評価及び現存するコミュニティ道路の評価、個人属性と 深い関わりがあることがわかった。しかし、コミュニティ道路の意義をまだ十分認識してない人も多くいるものと考えられ、 今後コミュニティ道路を面的に広げていくためには、これらの人の理解をどのようにして求めていくかが重要な課題となる。

\section{Analysis of the Attitude for Developing Traffic Calming Roads}

Yoriyasu SUGIE, Akimasa FUJIWARA and Hiroki TANABE This paper aims to evaluate traffic calming roads which have been completed since 1983 in Hiroshima through the public attitude survey and to obtain necessary information for their zonal development. Consequently, the roads are favored by the majority of surrounding residents, but they do not always desire the new roads cross to their houses. The reason seems to be that they are not well aware of current traffic situation of their neighborhood roads. The problem is how to make them understand the significance of traffic calming for further development of new roads. 